\title{
Persepsi tentang Seks Pranikah pada Remaja Putri yang Bertempat Tinggal di Kos dan di Rumah di Kasihan, Bantul
}

\author{
Umi Nur Isnaini ${ }^{1}$, Dewi Astiti², Dyah Pradnya Paramita ${ }^{3}$ \\ 1,2,3 Sekolah Tinggi IImu Kesehatan Alma Ata Yogyakarta \\ Jalan Ringroad Barat Daya No 1 Tamantirto, Kasihan, Bantul, Yogyakarta
}

\begin{abstract}
Abstrak
Perilaku seks pranikah yang saat ini sudah menjamur di kalangan remaja menjadikan remaja tidak tabu lagi dengan kata seks. Hasil pencatatan Kantor Urusan Agama Kecamatan Kasihan menunjukan peningkatan pernikahan di usia dini, yaitu dari 15 pasang remaja pada bulan Januari hingga Oktober, 16 pasang pada bulan November dan 33 pasang pada bulan Desember. Persepsitentang seks pranikah pada remaja ini perlu diketahui untuk meningkatkan kesadaran dan mengatasi tingginya angka seks pranikah di Yogyakarta. Penelitian ini bertujuan untuk mengetahui persepsi tentang seks pranikah pada remaja putri yang bertempat tinggal di kos dan di rumah di Kecamatan Kasihan Bantul. Penelitian ini menggunakan metode penelitian kualitatif. Narasumber penelitian ini adalah remaja putri yang bertempat tinggal di kos dan di rumah Kecamatan Kasihan Bantul yang sudah melakukan seks pranikah dan yang tidak melakukan seks pranikah. Teknik pencarian sampel dengan menggunakan purposive sampling dengan metode triangulasi. Instrumen yang digunakan adalah panduan wawancara persepsi tentang seks pranikah, perekam suara dan alat tulis. Hasil penelitian menunjukan bahwa pemahaman remaja hanya mengetahui sedikit tentang definisi seks pranikah, selain itu juga hanya mengetahui sebagian dampak seks pranikah dan faktoryang mendorong seks pranikah. Faktoryang paling banyakmendorong remaja melakukan seks pranikah adalah karena memiliki pasangan lawan jenis. Sikap remaja putri yang tidak melakukan seks pranikah menolak dan menghindari seks pranikah, sedangkan remaja yang sudah melakukan seks pranikah menolak seks pranikah namun melakukanya. Hasil penelitian menunjukan bahwa tidak terdapat perbedaan persepsi tentang seks pranikah remaja yang bertempat tinggal di kos dan di rumah, namun terdapat perbedaan persepsi tentang seks pranikah dan sikap remaja yang sudah melakukan seks pranikah dan yang tidak melakukan seks pranikah.
\end{abstract}

Kata Kunci: persepsi, seks, pranikah

\section{The Perception of Premarital Sex in Adolescent Girls who Live in Rent Room and Home at Kasihan, Bantul}

\section{Abstract}

Premarital sex now already spread among adolescent, it makes adolescent not taboo anymore with sex. The results of recording by office of religious in Kasihan showed an increase in marriage among an early age, from 15 adolescent couples in January to October, 16 adolescent couples in November and 33 adolescent couples in December. The perception of premarital sex in adolescent should be known to raise awareness and to increase the high number of premarital sex in Yogyakarta. This study was aimed to know the perception of premarital sex in adolescent girls who live in rent room and home at Kasihan, Bantul. This study was used qualitative methode. Speakers were adolescent girls who lived in rent room and home at Kasihan, Bantul who had done premarital sex and who did not. Samples was obtained by purposive sampling with the triangulation. An instrument was used an interview guide of premarital sex perception, recorder sound and stationery. The results showed that adolescent only know about some of the definition premarital sex, it was also only know a part of impact because premarital sex and factors that encourage premarital sex. Factors that the most encourages adolescent premarital sex was because they had boyfriend. Attitudes of adolescent girls who did not hold premarital sex refuse and avoid premarital sex, while adolescent who had been doing premarital sex refuse premarital sex but still did it. The results of this study showed that there was no different perceptions about sex premarital in adolescent girls who live in rent room and home, but there was a differences perception of premarital sex and attitude of adolescent who had been doing premarital sex and who not doing premarital sex.

Keywords: the perception of premarital sex

Info Artikel:

Artikel dikirim pada 9 Oktober 2014

Artikel diterima pada 9 Oktober 2014 


\section{PENDAHULUAN}

Masa remaja adalah suatu tahap kehidupan yang bersifat peralihan dan tidak mantap. Disamping itu, masa remaja adalah masa yang rawan oleh pengaruh-pengaruh negatif, seperti narkoba, kriminal, dan kejahatan seks. Seks bebas dapat membahayakan mereka karena bisa terjangkit berbagai penyakit kelamin. Namun, masa remaja ini juga masa yang amat baik untuk mengembangkan segala potensi positif yang mereka miliki seperti bakat, kemampuan, dan minat serta masa pencarian nilai-nilai hidup(1).

Data demografis menunjukan bahwa remaja merupakan populasi yang besar dari penduduk dunia. Menurut Biro Pusat Statistik di Indonesia kelompok umur 10-19 tahun adalah sekitar $22 \%$ yang terdiri dari 50,9\% remaja laki-laki dan $49,1 \%$ remaja perempuan(2).

Banyaknya angka remaja menyebabkan tingginya angka kenakalan remaja. Kenakalan remaja bukan disebabkan karena bandel, namun ada sebab lain seperti orang tua yang salah mendidik atau terlalu keras, terlalu memanjakan, dan pengaruh lingkungan.

Data Badan Koordinator Keluarga Berencana Nasional (BKKBN) pada tahun 2010 menunjukan $51 \%$ remaja di Jabodetabek telah melakukan seks sebelum mereka menikah, selain itu di Surabaya tercatat sebesar $54 \%$, Bandung $47 \%$, dan Medan $52 \%(3)$. Sebuah penelitian kehamilan di luar menikah menunjukan hasil 37\% dari 1.160 mahasiswi di Yogyakarta mengalami kehamilan sebelum menikah. Kehamilan merupakan salah satu akibat seksual yang dialami oleh remaja putri, jika dilihat hasil dari data BKKBN bisa ditarik kesimpulan bahwa rata-rata $50 \%$ remaja putri telah melakukan hubungan seksual di luar nikah.

Sejak tahun 2008 hingga tahun 2011 jumlah kasus pernikahan usia dini di Kabupaten Bantul DIY meningkat pesat karena hamil lebih dulu. Peningkatan tajam jumlah kasus pernikahan usia dini di kantor Pengadilan Agama Bantul, ditunjukkan dengan semakin banyaknya jumlah pasangan yang mengajukan permohonan dispensasi kawin yaitu tahun 2008 mencapai 70 pasangan, tahun 2009 sebanyak 82 pasangan, tahun 2010 meningkat menjadi 115 dan tahun 2011 menjadi 135 pasangan. Dari jumlah tersebut $90 \%$ diantaranya adalah pasangan usia dini yang mengalami kasus hamil sebelum nikah, dan $10 \%$ yang benar-benar ingin mengajukan pernikahan tanpa hamil duluan. Bukan hanya tingginya angka pernikahan di usia dini yang menjadi dampak dari perilaku seksual pada remaja, namun juga tingginya jumlah penderita AIDS yang tercatat dalam Komisi Penanggulangan AIDS tahun 2013 daerah Yogyakarta dengan 535 kasus, disusul daerah Sleman dengan 406 kasus, daerah Bantul 312 kasus, Kulonprogo dengan 94 kasus dan yang terendah yaitu daerah Gunung Kidul dengan 61 kasus(2).

Dari hasil pencatatan pernikahan Kantor Urusan Agama Kecamatan Kasihan menunjukan peningkatan angka pernikahan di usia dini yaitu usia 16-21 tahun. Pada bulan Januari hingga bulan Oktober hanya tercatat 15 pasang remaja yang mengajukan pernikahan di usia 16-21 tahun. Sedangkan pada bulan November terdapat 16 pasang yang mengajukan pernikahan di usia 16-21 tahun. Kemudian di akhir tahun, bulan Desember tercatat 33 pasang remaja yang mengajukan pernikahan di usia 16-21 tahun(4).

Remaja putri yang saat ini banyak mengalami kegagalan dalam menempuh pendidikannya akibat kehamilan di luar menikah, sebagian besar adalah remaja putri yang bertempat tinggal di kos. Namun, tidak semua yang bertempat tinggal di kos berani melakukan seks pranikah, ada juga remaja putri yang tinggal di rumah dalam pengawasan orang tua melakukan seks pranikah dengan teman lakilakinya. Remaja merupakan generasi penerus bangsa ini. Untuk mewujudkan cita cita itu remaja harus dikondisikan sebagai remaja yang handal dan dapat bertanggung jawab baik dalam aspek akademik, sosial hingga moral remaja itu sendiri.

Berdasarkan observasi yang peneliti lakukan di daerah Kasihan dan sekitarnya terdapat beberapa institusi perguruan tinggi, seperti Universitas Muhammadiyah Yogyakarta, STIKES A. Yani, STIKES Alma Ata, Universitas PGRI Yogyakarta, Yayasan Keperawatan Yogyakarta dan institusi pendidikan lainya. Hal tersebut menjadi salah satu penyebab banyaknya tempat tinggal kos para remaja dari berbagai daerah yang ingin menempuh pendidikan di daerah Kasihan, sehingga meningkatkan angka remaja yang berdomisili di daerah tersebut. Oleh karena itu peneliti tertarik untuk melakukan penelitian pada remaja putri di daerah Kasihan. Selain itu berdasarkan observasi yang peneliti lakukan pada remaja putri yang bertempat tinggal di kos, dari 15 orang responden hampir semua mengetahui tentang seks pranikah. Bukan hanya remaja putri yang bertempat tinggal di kos yang mengetahui seks pranikah, namun 5 remaja putri yang tinggal di rumah yang telah diobservasi oleh peneliti juga mengetahui tentang seks pranikah. Enam dari 15 orang responden 
yang bertempat tinggal di kos dan 2 dari 5 orang responden yang bertempat tinggal di rumah mengaku bahwa mereka pernah melakukan seks pranikah dengan teman laki-lakinya.

Tujuan penelitian untuk mengetahui persepsi tentang seks pranikah pada remaja putri yang bertempat tinggal di kos dan di rumah di Kecamatan Kasihan Bantul.

\section{BAHAN DAN METODE}

Jenis penelitian yang dipergunakan dalam penelitian ini adalah diskriptif kualitatif. Teknik pengumpulan data dilakukan secara triangulasi (gabungan), analisa data bersifat induktif. Rancangan penelitian yang digunakan dalam penelitian ini dengan menggunakan pendekatan cross sectional. Dalam penelitian kualitatif, tidak menggunakan populasi karena penelitian kualitatif berawal dari kasus tertentu yang ada pada situasi sosial tertentu dan hasil kajiannya tidak akan berlakukan ke populasi, tetapi dikirim ke tempat sosial lain yang memiliki kesamaan dengan situasi sosial pada kasus yang dipelajari(5). Dalam penelitian ini situasi yang diambil adalah seluruh remaja putri yang bertempat tinggal di Kasihan. Sampel dalam penelitian kualitatif bukan dinamakan responden, tetapi sebagai narasumber, partisipan, informan, teman, dan guru dalam penelitian. Sampel dalam penelitian kualitatif juga tidak disebut sampel statistik, tetapi sampel teoritis, karena tujuan penelitian kualitatif adalah untuk menghasilkan teori. Sampel dalam penelitian ini adalah remaja putri, pengasuh remaja putri meliputi orang tua dan pemilik kos, serta ketua RT setempat. Sampel yang digunakan pada penelitian ini adalah 20 remaja putri yaitu 10 remaja putri yang belum pernah melakukan hubungan seksual pranikah dan 10 remaja putri yang sudah melakukan hubungan seksual pranikah baik yang bertempat tinggal di rumah maupun yang bertempat tinggal di kos, pengawas remaja putri itu sendiri yaitu ibu kos remaja putri dan orang tua, dan 1 orang ketua RT setempat. Jadi total sampel yang digunakan adalah 23 narasumber. Teknik sampling merupakan teknik pengambilan sampel untuk menentukan sampel yang akan digunakan dalam penelitian. Salah satu teknik pengambilan sampel yang digunakan dalam penelitian ini adalah purposive sampling, yaitu teknik pengambilan sampel sumber data dengan pertimbangan tertentu, sehingga jika dalam proses penelitian narasumber yang digunakan peneliti belum memenuhi, peneliti dapat menambahkan narasumber dengan menggunakan kriteria yang sama(6). Tempat penelitian berada di wilayah Kecamatan Kasihan
Kabupaten Bantul yang akan dilaksanakan pada bulan Maret sampai Juni 2014. Dalam penelitian ini menggunakan variabel tunggal, yaitu persepsi tentang seks pranikah pada remaja putri.

\section{HASIL DAN BAHASAN}

\section{Karakteristik Narasumber}

\section{Pemahaman Tentang Seks Pranikah} Remaja Putri yang Bertempat Tinggal di Kos

Empat remaja putri yang belum melakukan hubungan seksual pra nikah mengartikan bahwa seks adalah hubungan suami istri yang dilakukan remaja laki-laki dan perempuan yang belum memiliki hubungan pernikahan.

Empat dari enam remaja putri yang sudah melakukan hubungan seksual pra nikah mengartikan seks pra nikah adalah hubungan suami istri yang dilakukan remaja yang belum memiliki status suami istri dan 2 lainnya mengartikan bahwa hubungan seks adalah segala hubungan laki laki dan perempuan yang sudah menikah dari suara sentuhan hingga perilaku yang hanya dilakukan suami dan istri.

\section{Remaja Putri yang Bertempat Tinggal di Rumah}

Tiga remaja putri yang belum melakukan hubungan seksual pra nikah mengartikan seks pra nikah adalah hubungan suami istri yang dilakukan remaja sebelum menikah.

Tiga remaja putri yang sudah melakukan hubungan seksual pra nikah juga mengartikan seks pra nikah adalah hubungan suami istri yang dilakukan remaja sebelum memiliki hubungan pernikahan sedangkan 1 remaja putri mengatakan bahwa seks adalah hubungan laki-laki dan perempuan yang dimulai dari sentuhan pegang tangan.

Orang tua yang memiliki anak remaja putri mengatakan bahwa seks pra nikah adalah hubungan suami istri yang dilakukan oleh remaja yang belum memiliki hubungan pernikahan.

Pemilik kos putri yang memiliki 2 tempat kos putri yang berbeda dan 1 kontrakan ini mengartikan bahwa seks adalah hubungan yang dimiliki suami istri saja, perilaku yang dilakukan dari suara dan sentuhan yang hanya dilakukan berdua yaitu suami dan istri.

Ketua RT mengartikan seks pra nikah adalah segala sesuatu yang memicu seorang remaja untuk melakukan aktifitas seksual mulai dari mendengar maupun melihat.

Dari hasil penelitian yang telah dilakukan, peneliti mendapatkan hasil bahwa pemahaman 4 remaja putri yang tidak melakukan seks pranikah dan bertempat tinggal di kos 3 remaja yang tidak melakukan seks pranikah dan 3 remaja yang sudah 
Tabel 1. Karakteristik Narasumber

\begin{tabular}{|c|c|c|c|c|c|}
\hline \multirow{2}{*}{ Narasumber } & \multirow{2}{*}{$\begin{array}{l}\text { Umur } \\
\text { (tahun) }\end{array}$} & \multirow{2}{*}{ Tempat Tinggal } & \multicolumn{2}{|c|}{ Melakukan Hubungan Seksual } & \multirow{2}{*}{ Keterangan } \\
\hline & & & $\mathrm{Ya}$ & Tidak & \\
\hline R1 & 19 & Di Kos & - & Tidak & RemajaPutri \\
\hline $\mathrm{R} 2$ & 20 & Di Kos & - & Tidak & RemajaPutri \\
\hline R3 & 19 & Di Kos & - & Tidak & RemajaPutri \\
\hline R4 & 18 & Di Kos & - & Tidak & RemajaPutri \\
\hline R5 & 20 & Di Kos & Ya & - & RemajaPutri \\
\hline R6 & 21 & Di Kos & Ya & - & RemajaPutri \\
\hline $\mathrm{R} 7$ & 20 & Di Kos & Ya & - & RemajaPutri \\
\hline R8 & 19 & Di Kos & Ya & - & RemajaPutri \\
\hline R9 & 20 & Di Kos & Ya & - & RemajaPutri \\
\hline R10 & 20 & Di Kos & - & Tidak & RemajaPutri \\
\hline R11 & 21 & Di Rumah & - & Tidak & RemajaPutri \\
\hline $\mathrm{R} 12$ & 20 & Di Rumah & - & Tidak & RemajaPutri \\
\hline R13 & 21 & Di Rumah & - & Tidak & RemajaPutri \\
\hline R14 & 21 & Di Rumah & Ya & - & RemajaPutri \\
\hline R15 & 21 & Di Rumah & $\mathrm{Ya}$ & - & RemajaPutri \\
\hline R16 & 20 & Di Rumah & $\mathrm{Ya}$ & - & RemajaPutri \\
\hline $\mathrm{R} 17$ & 21 & Di Rumah & $\mathrm{Ya}$ & - & RemajaPutri \\
\hline R18 & 37 & Di Rumah & - & - & Orang tua \\
\hline R19 & 47 & Di Rumah & - & - & Pemilik Kos \\
\hline R20 & 53 & Di Rumah & - & - & Ketua RT \\
\hline
\end{tabular}

Sumber: Data Primer 2014

melakukan hubungan seks pranikah dan bertempat tinggal di rumah terdapat kesenjangan dengan definisi dalam buku Soetjiningsih dan Windu, yaitu seks merupakan segala sesuatu yang berhubungan dengan jenis kelamin baik khayalan, suara, maupun sentuhan yang mengakibatkan meningkatkan gairah akibat rangsangan tersebut(7).

Begitupun dengan 4 remaja putri yang sudah melakukan seks pranikah dan bertempat tinggal di kos, namun 2 remaja lainya dan 1 remaja yang sudah melakukan hubungan seks bertempat tinggal di rumah memiliki pemahaman yang sesuai dengan definisi $\operatorname{seks}(7,8)$.

Orang tua yang memiliki anak remaja putri juga berpendapat bahwa seks hanya hubungan intim saja, menunjukan bahwa kurangnya pemahaman tentang arti seks. Namun pemilik kos dan ketua RT memiliki kesenjangan antara pemahaman mereka dengan definisi Soetjiningsih dan Windu.

Hasil penelitian ini berbeda dengan hasil penelitian Tutik Prastyaningsih yang melakukan penelitian pada siswa kelas XI MAN dan SMK Bopkri yang menunjukan hasil bahwa tingkat pengetahuan remaja tentang seks pranikah dalam kategori baik(9). Selain itu, hasil penelitian juga berbeda dengan penelitian yang dilakukan Naedi pada siswa kelas XI SMAN 1 Cileungsi yang menunjukan bahwa hasil pengetahuan remaja tentang definisi seks pranikah dalam kategori
baik(10).Dalam menyikapi perbedaan hasil penelitian ini, menurut peneliti kemungkinan perbedaan hasil penelitian disebabkan karena karakteristik responden yang berbeda dan cara menggali informasi yang dilakukan penelitian sebelumnya adalah Kuantitatif, menggunakan kuesioner sedangkan penelitian ini dengan wawancara mendalam persepsi tentang definisi seks pranikah yang diangkat oleh peneliti.

\section{Pemahaman Tentang Dampak Seks Pranikah}

\section{Remaja Putri yang Bertempat Tinggal di Kos}

Empat remaja putri yang belum melakukan hubungan seksual pra nikah mengatakan seks pra nikah adalah hubungan yang tidak sehat dan tidak wajar dilakukan oleh seorang remaja putri selain sebuah zina, seks pra nikah akan menimbulkan kehamilan dan penyakit menular seksual, hanya saja 3 remaja mengatakan bahwa dampak tersebut tidak dapat dicegah dan tidak dapat diobati, sedangkan 1 remaja mengatakan bahwa dampak tersebut tidak dapat dicegah namun dapat diobati dengan melakukan konsultasi dengan tenaga kesehatan.

Empat dari 6 remaja putri yang sudah melakukan hubungan seksual pra nikah berpendapat bahwa seks pra nikah merupakan sebuah kebutuhan rohani yang harus dipenuhi, selain itu remaja yang sudah melakukan hubungan seks pra nikah ini mengatakan bahwa seks itu sehat. Sedangkan 2 dari 6 remaja tersebut mengatakan bahwa seks pranikah itu tidak 
sehat dan tidak boleh dilakukan namun tidak dapat dihindari.

Dampak dari seks yang disebutkan 6 remaja putri mengatakan bahwa dampak seks pranikah seperti kehamilan dan penyakit menular seksual itu dapat dicegah dengan menggunakan kondom dan pandai pandainya kita melakukanya, sedangkan untuk pengobatanya dapat dikonsultasikan dengan tenaga kesehatan setempat.

\section{Remaja Putri yang Bertempat Tinggal di Rumah}

Tiga remaja putri yang belum melakukan hubungan seksual pra nikah berpendapat bahwa seks itu sehat, tetapi hal tersebut belum saatnya dilakukan oleh seorang remaja. Dampak dari seks pranikah yaitu gangguan pada organ reproduksinya yang belum siap untuk melakukan hubungan seksual yang tidak dapat dicegah jika remaja tersebut telah melakukan hubungan seksual pra nikah. Apabila tidak ingin mendapatkan dampaknya maka jangan melakukan hubungan seks pra nikah.

Empat remaja putri yang sudah melakukan hubungan seksual pra nikah memiliki pendapat yang hampir sama, yaitu seks itu sehat tetapi tidak wajar dilakukan oleh seorang remaja. Karena sudah terbiasa dengan hubungan seks pranikah, seorang remaja menjadi terbiasa dan menganggap hal tersebut sebuah kebutuhan. Tiga dari 4 remaja putri yang sudah melakukan hubungan seksual pra nikah ini juga mengatakan bahwa kehamilan dan penyakit yang ditimbulkan dari seks pra nikah dapat dicegah dengan menggunakan kondom, serta dapat diobati jika sudah terlanjur hamil dengan cara melakukan aborsi sedangkan jika mendapat penyakit menular seksual dapat melakukan konsultasi dengan dokter.

Orang tua yang memiliki anak remaja putri berpendapat bahwa seks itu kebutuhan dan kewajiban seorang istri kepada suaminya maka tidak boleh dilakukan oleh remaja, seks yang dilakukan remaja tidaklah sehat karena hal tersebut adalah zina. Dampak dari seks itu sendiri selain kehamilan dan penyakit menular seksual adalah gangguan moral pada seorang remaja, hingga gangguan psikologi seorang remaja. Dampak-dampak tersebut dapat di cegah apabila orang tua dapat mengontrol anaknya untuk tidak melakukan hubungan seksual pra nikah, untuk mengobati dampak kehamilan dapat di lakukan aborsi namun jika sudah terkena penyakit menular seksual tidak ada obatnya.

Pemilik kos putri menganggap bahwa seks itu tidak sehat dilakukan pada remaja karena dapat mengakibatkan kehamilan di luar pernikah yang nanti akan menyebabkan pernikahan setelah hamil dan remaja yang melakukan hubungan pranikah tersebut belum dapat menerima peran baru untuk menjadi seorang ibu dan ayah yang akan mengakibatkan kerusakan dalam rumah tangga yang dibina dengan perselingkuhan dan kenakalan lainnya.

Ketua RT setempat memiliki pandangan tersendiri tentang dampak dari seks pra nikah tersebut, selain karena seks itu tidak sehat dilakukan oleh seorang remaja, seks juga dapat menyebabkan seseorang mendapatkan sebuah kutukan dari Allah berupa penyakit menular seksual yang disebut HIV/ AIDS yang hingga saat ini tidak ada obatnya dan hanya bisa dicegah apabila remaja putri tersebut tidak melakukan seks bebas.

Setelah dilakukan wawancara kepada 17 remaja didapatkan pemahaman remaja tentang dampak seks pranikah tidak sesuai dengan teori. Semua remaja menganggap dampak seks hanya hamil dan penyakit menular seksual saja. Dalam definisi dampak seks pranikah menurut Santrock dan Kusmiran menunjukan bahwa dampak dari seks pranikah bukan hanya 2 hal tersebut namun juga dapat meningkatkan aborsi, gangguan psikologis, peningkatan kematian ibu dan peningkatan kematian $\operatorname{anak}(11)$.

Berdasarkan pendapat penanggungjawab anak yaitu orang tua dan pemilik kos dampak seks akan berakibat mempengaruhi ke psikologi anak tersebut sehingga akan mengganggu dalam proses rumah tangganya. Ketua RT setempat mengatakan bahwa dampaknya adalah penyakit HIVIAIDS.

Dengan kurangnya pemahaman yang dimiliki oleh remaja tentang dampak seks pranikah akan menyebabkan turunya kesadaran remaja untuk mengurangi perilaku seks pranikah dan membuat remaja berfikir bahwa dampak seks pranikah dapat diatasi. Peneliti berharap, dalam masa pertumbuhan dan perkembangan remaja dapat meningkatkan kesadaran dalam pola pikir remaja unuk meninggalkan perilaku seks pranikah.

\section{Pemahaman tentang Faktor yang Mempengaruhi Seks Pranikah}

\section{Remaja Putri yang Bertempat Tinggal di Kos}

Satu dari 4 remaja putri yang belum melakukan hubungan seksual pra nikah memiliki pandangan bahwa faktor yang paling besar mempengaruhi seorang remaja melakukan hubungan seks pra nikah adalah karena tingkat keimanan yang tipis dan 4 remaja tersebut menyebutkan pergaulan dengan teman yang sudah melakukan hubungan seksual pranikah akan mempengaruhi remaja untuk mengikuti melakukan hubungan seks pranikah.

Lima dari 6 remaja putri yang sudah melakukan hubungan seksual pra nikah berpendapat bahwa 
remaja putri melakukan hubungan seksual karena mereka memiliki pasangan lawan jenis dan waktu bersama yang lebih banyak sehingga menimbulkan rasa ingin melakukan hal yang lebih dan lebih hingga hubungan suami istri. Sedangkan faktor lain seperti teman, ekonomi maupun sosial tidak terlalu berpengaruh, karena yang dapat mempengaruhi diri sendiri hanyalah dirinya sendiri.

\section{Remaja Putri yang Bertempat Tinggal di Rumah}

Tiga remaja putri yang belum melakukan hubungan seksual pra nikah mengatakan bahwa faktor yang berpengaruh pada remaja putri melakukan hubungan seks pra nikah adalah karena faktor pergaulan dan lingkungan remaja itu sendiri.

Tiga dari 4 remaja putri yang sudah melakukan hubungan seksual pra nikah mengatakan bahwa faktor yang mempengaruhi remaja putri melakukan hubungan seks pra nikah bisa karena salah bergaul atau karena dorongan ekonomi yang rendah sehingga memicu remaja melakukan hubungan seks pranikah karena ingin mendapatkan imbalan pemenuhan kebutuhan yang diinginkan remaja itu sendiri yang tidak dapat dipenuhi oleh orang tua. Sedangkan 1 remaja mengatakan bahwa faktor yang paling memepengaruhi remaja melakukan hubungan seks pranikah adalah karena memiliki pasangan

\section{Orang Tua yang Memiliki Anak Remaja Putri}

Mengatakan bahwa faktor yang paling besar mempengaruhi remaja melakukan hubungan seks pra nikah karena perkembangan IT yang sangat pesat, sehingga remaja dapat mengakses berbagai informasi yang seharusnya tidak didapatkanya sehingga menimbulkan rasa ingin tahu yang lebih dan merusak bagian otak dari remaja tersebut untuk melakukan pemberontakan kepada orang tua dan rasa penasaran yang tinggi tentang seksualitas yang akan di luapkan kepada pasangan lawan jenisnya.

\section{Pemilik Kos Putri}

Mengatakan bahwa faktor yang berpengaruh adalah karena faktor orang tua dalam memberikan pendidikan anak dari kecil serta pergaulan anak tersebut.

\section{Ketua RT Setempat}

Mengatakan bahwa hal yang paling mempengaruhi remaja putri melakukan hubungan seks pra nikah adalah perkembangan IT yang digunakan dari sisi negatifnya saja. Namun faktor pergaulan, ekonomi dan sosial juga dapat mempengaruhi remaja putri melakukan hubungan seks pranikah terutama pada remaja yang bertempat tinggal di kos karena tidak ada yang mengawasi khusus secara dekat dan nyata.

Menurut hasil wawancara yang telah dilakukan peneliti, faktor yang paling mempengaruhi remaja melakukan seks pranikah menurut remaja yang tidak melakukan seks pranikah adalah faktor teman dan lingkungan. Sedangkan menurut remaja yang sudah melakukan seks pranikah karena faktor diri sendiri dan memiliki pasangan lawan jenis(12).

Berbeda dengan remaja, penanggung jawab anak dan ketua RT beranggapan bahwa faktor yang paling mendukung remaja melakukan seks pranikah adalah karena kemajuan teknologi yang digunakan kurang baik. Faktor yang disebutkan oleh remaja tersebut merupakan beberapa faktor yang disebutkan didalam definisi Soetjiningsih dan Santrock. Dalam hal ini remaja memiliki pemahaman yang sesuai dengan teori(7).

Dalam penelitian Naedi, faktor yang mempengaruhi remaja melakukan seks pranikah adalah karena kurangnya informasi tentang seks(10). Hasil penelitian yang telah dilakukan peneliti ini menunjukan bahwa faktor yang mendorong perilaku seksual adalah karena memiliki pasangan dan sering bertemu dengan pasangannya, selain itu juga karena faktor lingkungan pergaulan dengan teman yang kurang baik.

Menurut peneliti perbedaan hasil penelitian disebabkan karena perbedaan karakteristik narasumber yang berbeda dan lingkungan narasumber yang diambil oleh peneliti. Mendapatkan hasil penelitian tersebut, peneliti berharap remaja dapat meningkatkan keimanan agar tidak melakukan perilaku yang menyimpang seperti seks pranikah, selain itu juga menghindari pasangan yang mengajak dalam perilaku yang menyimpang.

\section{Sikap Remaja Putri Terhadap Seks Pranikah Remaja Putri yang Bertempat Tinggal di Kos}

Empat remaja putri yang belum melakukan hubungan seksual pra nikah beranggapan seks pranikah adalah yang sangat tercela dan dapat dipengaruhi oleh faktor pergaulan, sehingga remaja putri harus membatasi pergaulan dan menjaga jarak dengan teman yang sudah melakukan hubungan seks pranikah. Hal ini menunjukan bahwa sikap remaja menolak dengan seks pranikah dan menghindari.

Enam remaja putri yang sudah melakukan hubungan seksual pra nikah memiliki pendapat bahwa seks itu memang tidak boleh dilakukan oleh seorang remaja yang belum miliki hubungan pernikahan, namun yang dapat menyebabkan remaja melakukan seks pra nikah adalah dirinya sendiri, maka tidak perlu membatasi teman, yang perlu dilakukan remaja putri agar tidak melakukan seks pranikah adalah dengan mengatur dan menjaga dirinya sendiri, seperti 
meningkatkan keimanan. Hal tersebut menunjukan bahwa remaja menunjukan mereka mengetahui hal itu negatif tetapi tidak dapat dihindari atau menerimanya.

\section{Remaja Putri yang Bertempat Tinggal di Rumah}

Remaja putri yang belum melakukan hubungan seksual pra nikah berpendapat bahwa remaja harus pandai pandai memilih teman, membatasi pergaulan dan menjauhi teman yang telah melakukan hubungan seks pranikah.

Remaja putri yang sudah melakukan hubungan seksual pra nikah mengatakan bahwa seks itu memang tidak baik namun susah untuk dihindari karena sudah terjerumus.

Orang tua yang memiliki anak remaja putri mengatakan bahwa untuk menjaga anak putrinya agar tidak melakukan hubungan seksual pra nikah, maka orang tua tidak boleh bosan mengingatkan anaknya, memberikan siraman rohani, dan yang paling penting adalah mendidik anak dalam bimbingan agama agar hati dan pikiran anak senantiasa bersih. Selain itu orang tua juga harus membatasi jam main anak, seperti harus di rumah pada jam 9 malam, mengetahui teman teman anaknya untuk mencegah hal tersebut terjadi pada anaknya.

Pemilik kos mengatakan bahwa seks pranikah itu tidak boleh dilakukan. Namun selama remaja yang melakukan baik dengan pemilik kos maka pemilik kos juga akan bersikap baik dengan mereka karena itu merupakan urusan masing-masing. Pernyataan tersebut terlihat bahwa pemilik kos dapat menerima perilaku seks pranikah.

Ketua RT memiliki pendapat yang sangat komplek tentang seks pra nikah pada remaja saat ini. Seks pra nikah adalah zina yang harus dihindari oleh remaja. Untuk mengontrol seorang remaja putri memang lebih susah, maka penanggung jawab remaja putri tersebut baik orang tua maupun ibu kos harus memiliki hubungan yang baik sehingga terdapat keterbukaan antaranak dan penanggung jawab. Selain itu juga membatasi pergaulan anak dengan benar benar mengetahui aktivitas remaja putri sehari hari, seperti apabila pamit ijin pulang malam dengan alasan mengerjakan tugas, hendaknya orang tua benar benar mengetahui remaja tersebut tidak menggunakan waktu di luar rumahnya untuk hal yang negatif. Selain itu, remaja juga harus mendapatkan pendidikan seks yang baik dan secara dini dengan sejelas jelasnya sehingga dapat meningkatkan kesadaran tentang seksualitas. Siraman rohani juga sangat penting diberikan kepada remaja agar mereka memiliki tingkat keimanan yang kuat sehingga tidak mudah terayu dengan pergaulan dan lingkungan yang kurang baik.

\section{SIMPULAN DAN SARAN}

Berdasarkan hasil penelitian dan pembahasan yang telah dilakukan dapat disimpulkan tidak terdapat perbedaan persepsi tentang definisi seks pranikah pada remaja yang sudah melakukan hubungan seks pranikah maupun yang tidak melakukan hubungan seks pranikah baik yang bertempat tinggal di kos maupun di rumah. Terdapat perbedaan persepsi dampak seks pranikah pada remaja yang sudah melakukan hubungan seks pranikah dan yang tidak melakukan hubungan seks pranikah baik yang bertempat tinggal di kos maupun yang bertempat tinggal di rumah. Terdapat perbedaan persepsi faktor pendorong remaja putri melakukan hubungan seks pranikah yaitu, remaja yang sudah melakukan hubungan seks pranikah memliki persepsi bahwa diri sendiri dan memiliki pasangan lawan jenis sebagai penyebab banyaknya remaja putri yang melakukan hubungan seks pranikah, sedangkan remaja putri yang tidak melakukan hubungan seks pranikah memiliki persepsi bahwa karena faktor lingkungan dan teman yang mempengaruhi remaja putri untuk melakukan hubungan seks pranikah. Terdapat perbedaan sikap remaja yang sudah melakukan hubungan seks pranikah dengan remaja yang tidak melakukan hubungan seks pranikah yaitu, remaja yang sudah melakukan hubungan seks pranikah menolak dengan seks pranikah, namun tidak dapat menghindarinya. Sedangkan remaja yang tidak melakukan hubungan seks pranikah menolak seks pranikah dan berusaha menjauhi dan tidak melakukanya. Saran agar para orang tua lebih memperhatikan anak mereka dan para pemilik kos lebih ketat dalam memberikan ijin bertamu.

\section{RUJUKAN}

1. Willis S S. Remaja dan Masalahnya. Bandung: IKAPI; 2012.

2. BPS. Badan Pusat Statistik. Yogyakarta; 2013.

3. BKKBN. Program KB Nasional. BKKBN. Yogyakarta; 2013.

4. KUA Kecamatan Kasihan. Kantor Urusan Agama. KUA. Kasihan; 2013.

5. Margono. Metodologi Penelitian Pendidikan. Jakarta: RinekaCipta; 2010.

6. Sugiyono. Memahami Penelitian Kualitatif. Bandung: IKAPI; 2013.

7. Soejtiningsih. Tumbuh Kembang Remaja dan Permasalahanya. Jakarta: Sagung Seto; 2010.

8. Windu SC. Disfungsi Seksual-Tinjauan Fisiologis dan Patologis Terhadap Seksualitas. Yogyakarta: ANDI; 2009. 
9. Tutik S. Perbedaan tingkat pengetahuan tentang seks pranikah siswa kelas XI MAN II Wates dan SMK Bopkri Wates. STIKES AIma Ata Yogyakarta; 2011.

10. Naedi. Gambaran tingkat pengetahuan seks bebas pada remaja kelas XI di SMA Negeri I Cileungsi. Universitas Indonesia. Jakarta; 2012.
11. Kusmiran E. Kesehatan Reproduksi Remaja dan Wanita. Jakarta: Salemba Medika; 2012.

12. Santrock JW. Adolescence Elevent Edition. Jakarta: Erlangga; 2007. 